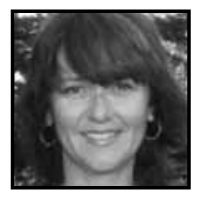

\title{
Narrative Insights: A Creative Space for Learning
}

\author{
Marcea Ingersoll, Queen's University
}

\section{ABSTRACT}

Through this scholarly personal narrative, the author offers insight into how student creativity can be engaged or neglected. While the narrative highlights the potential conflict between students' lives and their schools, the hope lies in the illuminative power of stories of difficulty. By interweaving narrative and theory, the author sheds light on the conditions that inhibit creativity, and emphasizes the capacity of teachers to locate creative, compassionate spaces for themselves and their students.

\section{Introduction}

f you want to write but feel you can't, you are not alone (Elbow, 1998). What is it that makes writing simultaneously appealing and daunting? In "Writing without Teachers," Elbow claims that many of us have an internal editorial filter that we place between our creative thoughts and the page, and that this "is partly because schooling makes us obsessed with the 'mistakes' we make in writing" (p. 5). How can we as teachers help students move beyond the fear of writing and lead them to its appeal? Perhaps we need to move beyond our own fears - to write and share our own stories with our students. We need to create opportunities for students to be comfortable writing with their teachers, rather than without (or for) them.

In the short piece, Lessons, in Writing, I explore personal memories of schooling that surfaced when I engaged in writing practices that were part of a graduate education class. Using scholarly personal narrative (Nash, 1994) to reach into my own pedagogical past, I found a creative space for representing the difficulty that arises when teachers correct students' "mistakes" of language. I present this narrative as a location for dialogue about home language, school language, and teaching. 
By interrupting the personal narrative with scholarly quotations, I direct teachers to works that provide further insight into the links between language, narrative, and identity. The symbiosis of personal narrative and scholarly text points teachers to the possibilities offered through creative engagement with stories of our educational selves.

\section{LESSONS, in Writing}

"I trust you will use writing as a method of inquiry to move into your own impossibility where anything might happen - and will"

(Richardson \& St. Pierre, 2005).

\section{Monday. Social Studies.}

Above the green chalkboard, curling posters of the provinces form a neat line from west to east. British Columbia's dawn redwoods. The prairies. The crags of Newfoundland. Beneath them, with equal precision, is the perfectly executed script that we must record. We copy the notes obediently. Mrs. Dominion circles, silent, hands on hips. She patrols the rows, nodding her approval to those who reproduce her elegant penmanship.

My hand sends the pencil across the page, an effortless translation of words from board to paper while my mind roams elsewhere. I am not in the room. I am not copying notes. I am anyone else but me and anywhere else but here.

\section{CRACK!}

Mrs. Dominion's precious silver chalk holder has dropped onto the floor next to my desk. The tiny clip lying lengthways along the barrel has broken, and on its descent the chalk has streaked a white line onto her navy slacks. Leaning over to pick up the fallen bullet, Mrs. Dominion's eyes fix on my page. She straightens.

- Your margins!

- Yes?

- They're drifting.

- Oh...yes.

- They're positively unmoored.

- $\quad$ Yes. Um...I'm sorry, Mrs. Dominion. 
- $\quad$ Class, you will mind your margins! THIS (my looseleaf flutters in the air) is unacceptable. It's uncontrolled!

Mrs. Dominion puts her chalk holder carefully onto the desk and smoothes the white blemish from her slacks. Then she tells us to go home and find out more information for our exchange projects on the fishery. Finish our research about what goes on in our community, and come back next week with something about what makes this tiny island in the Bay of Fundy work.

"Canadian identity is not unified or seamless, but shifts according to the particularity of language, geographical affiliations, and historical circumstances"

(Sumara, Davis, \& Laidlaw, 2001).

\section{Wednesday. Home.}

I know quite a bit already. After all, I always saw the boats go out, waited for my dad to come back after being away for a week, dreaded church on Sundays not just because the minister scared the bejeesus outta me but mostly because after the service, the menfolk would head to the wharves. It would be a long week, but our mothers made it go by with Koolaid, Kraft Dinner, grilled cheese. Serial sunburns and sand in our swimsuits as we played hide and seek, laid in the grass, and counted the stars.

Friday afternoons we'd wait at the end of the wharf, sitting on the hood of the car until someone called out here they come! Mothers would pull on shirttails and try and keep us from going near the wharf edge. The men aboard would stand and wave as the bow of the boat met each wave and came closer, closer. We'd have been cleaned up, face cloths dragged across our mouths and our small hands like flags flapping off their poles and popsicles melting down our shirtfronts. We'd look out! as the heavy ropes were flung onto the wharf and looped around the pilings. Then there was the slinging of duffle bags and thump, thump, thump, six landings of unwashed fish clothes, followed by the men, climbing up the ladders and over the lip of the wharf. The lifting, lifting, hugging of kids while mothers made sure no one was too close to the edge. Mothers moved over and dads went behind the wheel, driving home for Friday night baths and creaky bedsprings. Saturdays were for baked beans simmering in molasses, golden loaves of homemade bread, full clothes lines, and mowing the lawn with Dad.

"As a conscious professional pedagogue, I find the need to tell my stories, mostly to myself but sometimes to others, to make meaning of my existence"

(Fowler, 2006). 


\section{Friday. Home.}

I've asked my dad about the seines and sheds, asked him lots of questions about how they used to smoke the herring, what kinds of nets they use now on the seiner, who gets to do what. He's told me lots of stuff; told me about the herring his mum used to bone down at the shed, how her fingers were raw and stiff and sore. Told me about the golden smell in the rafters of the smoke house where they hung the herring sticks row on row. Different game now, he says, and tells me about the long old steam down to Yarmouth, half asleep in the wheelhouse, pitching along with the waves. Climbing down into the engine room-he keeps it neat as a pin mum says-he checks the gauges and makes sure everything is just right. They set seine after midnight, shine their lights and wait for the silver slips of fish to come to them. They circle, circle, tighten the purse and bring it up, a boiling surface of scales and flesh that gets pumped aboard and measured by the hogshead. This is what he gets up to, Dad tells me, when he goes out in the boat on Sundays, comes home on Fridays. But he doesn't mention the little bandaid-like patch he puts behind his ear to keep him from pitching his guts overboard, or how he ripped the heck outta his shoulder when he went overboard last time they were down in Novi-these are the bits I catch by mistake, when I'm not supposed to be listening.

"Different languages and different discourses within a given language divide up the world and give it meaning in ways that are not reducible to one another. Language is how social organization and power are defined and contested and the place where one's sense of self-one's subjectivity-is constructed"

(Richardson \& St. Pierre, 2005).

\section{Monday. Social Studies.}

We're all ready to tell our bits about the island fishery. We're gonna combine our projects and put them all in an envelope and send them off to a class of farm children on the prairies. They've probably never even seen the ocean or been aboard a fishing boat. Probably don't even know what a kipper is.

Gleaming with the fill of stories Dad told me, I was ready. And when Mrs. Dominion asked me the question on Monday, what did you find out, Marcea? I couldn't wait to tell. Breathless with excitement, I began.

I found out about the fish scaler. It's the machine they use to take the scales off the herring. They use the scales to make fingernail polish! I didn't know that before. Anyways, my dad told me about the scaler on the herring seiner, and on Sunday before they left, I seen the way it works. 
You what?

My dad told me about the scaler on the herring seiner, and on Sunday before they left, I seen the way it works. I repeated, slowed, convinced she hadn't heard. She ignored us a lot. I also reckoned she might have a problem with her ears, you know.

But that wasn't the problem. The problem was me. Mrs Dominion smiled that same little smile she got on her face whenever she was ready to pounce on one of the small children abandoned to her care.

You what? She asked again, although it didn't sound much like a question. And I was neither breathless nor enthusiastic for this retelling.

I seen the scaler, on the seiner down at the wharf, and I seen how it works. I can tell you what I seen...

No, you can't, she said, as I turned red, red, red...

and she began to write on the board, and I grew small, small, small...in my chair.

You will write 100 times for tomorrow....I will never say I seen.

\section{Today.}

And I haven't. I've never said it again. I wrote those hundred lines. Hunched over the kitchen table I held two pens in my cramped hand to scrawl in shaky lines across the looseleaf. Thought of my dad out on the boat, bit my lip, and moored my error tight against the margins. And with each line, these words of my father were erased forever from my own discourse and etched into ink, locked onto the page.

"To embrace narrative is to live into an image of the self, a construct of who we wish, or fear, to be. There can be nostalgia associated with such images, too: the point of the story, after all, is to comfort us, to help us make sense of what we think we were, or imagine we have become"

(Zwicky, 2006). 
I embraced narrative in a graduate class where the freedom to write without censure gave rise to creativity. As we moved through writing practices (Luce-Kapler, 2004) that encouraged us to reach into the educational stories of ourselves, I entered places long forgotten, deeply buried, but in need of surfacing. And as these experiences of stifled creativity and voice were given space to emerge, they became transformed into stories of power and realization. How had my own teaching been influenced by my experiences as a student? How could I move beyond censure?

Fowler (2006) suggests that through a process of narration and analysis, we can enact intentional pedagogical movement and more productive pedagogical relations. Through our willingness to engage in the storying of difficulty, we can safely illuminate the underside of teaching, and confront those experiences that are difficult to accept or know. Fowler identifies stories as places where we can store our difficulties, hold them in the vessel, or temenos of analysis, and learn from them. Lessons, in Writing represents a narrative exploration of the tensions presented when negotiating the borderlands of identity. By holding this story in the temenos, by analyzing the interaction of the teacher and student and family and community, I open a space for dialogue about the disruptive and discouraging nature of correction, censure, and enforced conformity.

By examining our untold stories, we can come to know ourselves in ways that make us better teachers. Last year I shared Lessons, in Writing with my students, who are teacher candidates at a faculty of education. I was encouraged by the connections they made to their own experiences as students, and their desires for themselves as teachers. One teacher candidate sent me a copy of Carol Ann Duffy's poem, "Originally," and highlighted the lines that brought these texts together for her. Another shared her experience of linguistic difference and isolation when she entered university and left the linguistic familiarity of her small town. She expressed, haltingly, her sense of being not "quite as good as, or as educated as" the others, because of the way she spoke.

These connections point to the possibility created in sharing stories of pedagogical experience. Teachers are always at the borders of the geographies of identity that we claim or deny. The geographies of our childhoods continue to be places we inhabit in conscious and unconscious ways. By examining our pasts, we can come to understand that the traces of our histories, our geographies, sometimes imprint themselves on our bodies and in our voices. We can begin to understand that-as teachers-we are also texts our students read. And by sharing these experiences through narrative, there is an opportunity for pedagogical moments to emerge, for 
intertextual and interpersonal connections to be made. There is a creative, intimate, trusting space that opens when we search for and share narrative insights.

\section{References}

Elbow, P. (1998). Writing without teachers (2nd ed.). New York: Oxford University Press.

Fowler, L. C. (2006). A curriculum of difficulty: Narrative research in education and the practice of teaching. New York: Peter Lang.

Luce-Kapler, R. (2004). Writing with, through, and beyond the text: An ecology of language. Mahwah, NJ: Lawrence Erlbaum.

Nash, R. J. (2004). Liberating scholarly writing: The power of personal narrative. New York: Teachers College Press.

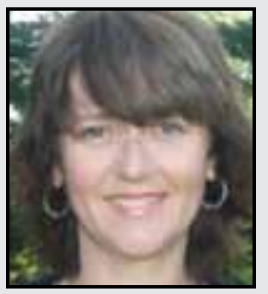

Marcea Ingersoll is a Maritimer by birth and a global nomad by nature. She has been an English teacher for nearly seventeen years, and has worked in Canadian, British, and American curriculum schools on three continents. Most of her teaching experience has been with students in Grades 7 to 12, but she has also taught at the university, college, and primaryjunior levels. Marcea is a PhD student in Curriculum Studies at Queen's University, where she continues to teach and to learn. Her current research interests include international schools and their communities, narrative inquiry, and teacher identity. 